\title{
The effects of diet on circulating sex hormone levels in men
}

\author{
Naomi E. Allen* and Timothy J. Key \\ Imperial Cancer Research Fund Cancer Epidemiology Unit, Gibson Building, \\ Radcliffe Infirmary, Woodstock Road, Oxford OX2 6HE, UK
}

There is considerable epidemiological evidence that a Western-style diet may increase the risk of certain hormone-dependent conditions in men via its effects on hormone metabolism. Experimental evidence also suggests that dietary factors may exert subtle effects on hormone metabolism. Here we review the clinical and epidemiological evidence that diet is associated with circulating sex hormone levels in men. In comparison with factors such as age and BMI, nutrients do not appear to be strong determinants of sex hormone levels. Dietary intervention studies have not shown that a change in dietary fat and/or dietary fibre intake is associated with changes in circulating sex hormone concentrations over the short term. The data on the effects of dietary phyto-oestrogens on sex hormone levels in men are too limited for conclusions to be drawn. Observational studies between men from different dietary groups have shown that a vegan diet is associated with small but significant increases in sex-hormone-binding globulin and testosterone concentrations in comparison with meat-eaters. However, these studies have not demonstrated that variations in dietary composition have any long-term important effects on circulating bioavailable sex hormone levels in men. This lack of effect may be partly explained by the body's negative feedback mechanism, which balances out small changes in androgen metabolism in order to maintain a constant level of circulating bioavailable androgens. It appears, therefore, that future studies should look for dietary effects on the feedback mechanism itself, or on the metabolism of androgens within the target tissues.

Diet: Sex hormones: Men

\section{Introduction}

The effects of diet on circulating sex hormone levels are potentially of great importance for the prevention of hormone-related disease. Sex hormones influence the development of prostate cancer, now the commonest cancer in men in some Western countries (Parkin et al. 1992). Sex hormones also influence a variety of other conditions in men, such as infertility (Kaiser et al.

\footnotetext{
Abbreviations: A-diol-g, androstanediol glucuronide; DHT, dihydrotestosterone; FT, free testosterone; LH, leuteinising hormone; SHBG, sex-hormone-binding globulin.

*Corresponding author: Naomi Allen, fax + 44 1865301545, email n.allen@icrf.icnet.uk
} 
1988), low sperm count (Lee et al. 1998; Liu et al. 1999), and benign prostatic hyperplasia (Denis et al. 1999). Diet-related changes in hormone metabolism may also be of interest to elite athletes, who may benefit from maximising anabolic steroid production to enhance physical performance (Brotherhood, 1984; Miller \& Wolfe, 1999). Dietary habits are changing rapidly across the world, with many developing countries increasing their per capita consumption of animal fat and protein in line with a more Western diet. Conversely, large numbers of Westerners are adopting a semi-vegetarian or vegetarian diet, and the number of vegans (who eat no animal products at all) is increasing (Ball, 1997; Vegetarian Society UK, 2000). It is therefore of great importance to understand the effects of such large-scale changes in diet on sex hormone metabolism.

The present review evaluates the epidemiological evidence for diet-related changes in circulating concentrations of sex hormones in men. Much of the research has focused on the hypothesis that a low-fat high-fibre diet is associated with lower androgen concentrations. An outline of the biology of sex hormones in men is given first, and the proposed biological mechanisms through which dietary factors may influence sex hormone production and/or metabolism are reviewed. The clinical and epidemiological studies that have examined the relationship between diet and sex hormone levels in men are then reviewed and their findings discussed.

\section{The biology of sex hormones in men}

Sex steroid hormones are mitogens and promote growth of cells in many target organs. In men, androgens stimulate male sexual differentiation and development, pubertal masculinisation, initiation of spermatogenesis and maintenance of sexual function. An overview of the relationships between hormone secretion, target tissues and androgen metabolism is given in Fig. 1 . Testosterone is synthesised from cholesterol in Leydig cells within the testes, with production being stimulated by secretion of luteinising hormone ( $\mathrm{LH})$ from the anterior pituitary gland. In turn, the pulsatile secretion of gonadotrophin-releasing hormone from the hypothalamus regulates LH secretion. Once testosterone enters the general circulation, a large percentage (approximately 50\%) is tightly bound to sex-hormone-binding globulin (SHBG) and is considered unavailable for biological action (Coffey \& Isaacs, 1981). Testosterone is also bound to albumin (approximately 48\%), but with much lower affinity than for SHBG, and this albuminbound testosterone probably serves as a buffer to protect testosterone from rapid metabolism (Manni et al. 1985). The remaining testosterone (approximately 2\%) is unbound or free testosterone (FT). Only testosterone that is not bound to SHBG (i.e. FT and albumin-bound testosterone) can enter target tissue cells by passive diffusion. For the purpose of the present review we will generally restrict discussion of the bioavailable fraction of testosterone to measurements of FT. The amount of testosterone that is freely available to enter cells is largely determined by the circulating concentration of SHBG. A relatively small increase in plasma SHBG concentration will produce a large reduction in the amount of circulating FT (Dunn et al. 1981).

Testosterone production is regulated by negative feedback of circulating testosterone on LH secretion, so that high levels of circulating testosterone lead to a reduction in the frequency and amount of pulsatile LH release. This process can occur both directly and after testosterone is aromatized to oestradiol, as oestrogens also exert a negative feedback on LH secretion (Marynick et al. 1979; Kletter et al. 1997). Cross-sectional studies of samples of normal men invariably show a positive correlation between serum concentrations of testosterone and 


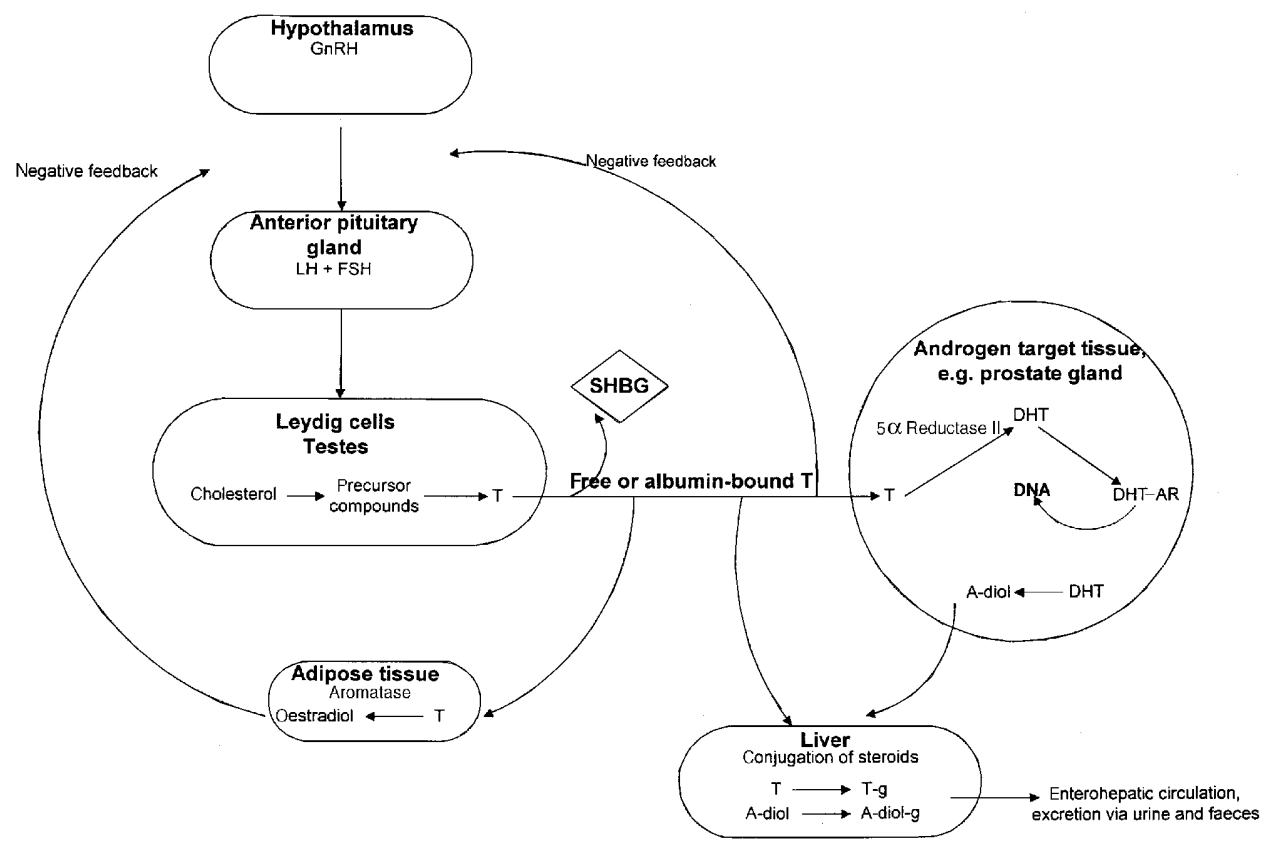

Fig. 1. Main pathways of androgen action and metabolism. A-diol, androstanediol; A-diol-g, androstanediol glucuronide; AR, androgen receptor; DNA, deoxyribonucleic acid; DHT, dihydrotestosterone; $\mathrm{FSH}$, follicle-stimulating hormone; $\mathrm{GnRH}$, gonadotrophin-releasing hormone; $\mathrm{LH}$, luteinising hormone; SHBG, sex-hormone-binding globulin; T, testosterone; T-g, testosterone glucuronide.

SHBG, because high concentrations of SHBG reduce the proportion of testosterone that is bioavailable, therefore the total concentration of testosterone increases to produce adequate levels of bioavailable testosterone.

Androgenic action is mediated once non-SHBG-bound testosterone enters the target cells, such as the epithelial cells of the prostate and seminal vesicles. Most of the testosterone is then irreversibly reduced into its more active form, dihydrotestosterone (DHT), by $5 \alpha$-reductase type II (Bruchovsky et al. 1988). Some of the DHT re-enters the blood, and circulating DHT is almost entirely derived from this peripheral conversion of testosterone. Although the circulating concentration of testosterone is approximately ten times higher than that of DHT, organs such as the prostate gland contain much greater levels of DHT than testosterone (Coffey \& Isaacs, 1981). DHT is the principal growth-regulating androgen because it has a much higher affinity to bind to the androgen receptor than testosterone. Once bound to the androgen receptor, the resultant complex is transported to the nucleus to transactivate target genes involved in cell growth and other androgen-dependent activities (Wilding, 1995).

The serum concentration of DHT has limited value as a marker of peripheral androgen metabolism. Most DHT formed in the prostate does not enter the circulation, but is metabolised within the prostate to androstanediol, which is mostly conjugated to its glucuronide form (Adiol-g) in the liver before excretion (Rittmaster et al. 1993). The serum concentration of A-diol$\mathrm{g}$ is thought to be a reasonably specific marker of intra-prostatic DHT and $5 \alpha$-reductase activity (Rittmaster et al. 1993; Thigpen et al. 1993). 
Approximately $75-90 \%$ of circulating oestrogens in men are derived from extraglandular aromatization of testosterone and androstenedione (largely derived from the adrenal glands), to oestradiol and oestrone respectively, in adipose tissue (Farnsworth, 1996). Oestrogens have a stimulatory effect on cell growth (Ehrlichman et al. 1981), especially in the prostate gland as they exist at much higher levels in this organ than in plasma or in skeletal muscle (Belis, 1980).

Steroids are conjugated with glucuronic acid and $\mathrm{H}_{2} \mathrm{SO}_{4}$ in the liver, secreted in bile, and enter the enterohepatic circulation. Here they are either hydrolysed and reabsorbed into the bloodstream and are ultimately excreted via the kidneys, or are excreted via the faecal route (see p. 164).

\section{Non-dietary determinants of sex hormone levels in men}

\section{Age}

It is now well documented that circulating androgen levels in men decline with age. Total testosterone falls by about $18-25 \%$ between the ages of 20 and 70 years (Gray et al. 1991; Simon et al. 1992; Wu et al. 1995; Morley et al. 1997). Accompanying this decline in plasma testosterone concentration is a larger age-associated increase in the plasma SHBG concentration of 30-50\% between the ages of 20 and 70 years (Field et al. 1994; Wu et al. 1995; Lecomte et al. 1998). This causes a more pronounced decline in FT concentration of 40-50\% (Dai et al. 1981; Korenman et al. 1990; Nahoul \& Roger, 1990; Gray et al. 1991), which is accompanied by a small increase in the LH concentration (Morley et al. 1997). The total oestradiol concentration might be expected to fall with age due to the decline in testosterone concentrations. However, the usual increase in body fat with age increases the conversion of testosterone to oestradiol, and therefore is likely to offset this reduction. A failure to account for variations in BMI may have contributed to the inconsistencies of this association in the data (Gray et al. 1991; Ferrini \& Barrett-Connor, 1998). The level of oestradiol that is biologically available falls with age because of the corresponding rise in SHBG concentration (Ferrini \& Barrett-Connor, 1998).

The fall in testosterone production with increasing age is largely caused by a reduction in Leydig cell mass and function (Gooren, 1996). It has also been suggested that both the frequency and amplitude of LH pulsatile secretion are reduced with age (Kaufman et al. 1990). This process leads to a gradual failure of LH to respond sufficiently to the decline in testosterone levels, resulting in an eventual increase in circulating LH concentration in an attempt to stimulate testosterone production (Zwart et al. 1996). The reduced testosterone production is then unable to compensate for the fall in FT caused by the rise in SHBG concentration (Winters \& Atkinson, 1997). The reasons why SHBG concentration increases with age remain to be clarified, but may relate to the age-associated decline in levels of growth hormone and/or insulin-like growth factor-I levels (Vermeulen et al. 1996; Lecomte et al. 1998).

\section{BMI}

Another well-established determinant of hormone levels is BMI $\left(\mathrm{kg} / \mathrm{m}^{2}\right)$. There is a $20-30 \%$ reduction in testosterone concentration between clinically-obese men (BMI $\geq 30 \mathrm{~kg} / \mathrm{m}^{2}$ ) compared with lean men (BMI $<20 \mathrm{~kg} / \mathrm{m}^{2}$ ) (Field et al. 1994; Wu et al. 1995; Vermeulen et al. 1996; Ferrini \& Barrett-Connor, 1998) and up to a $40 \%$ reduction in SHBG concentration between lean and clinically-obese men (Field et al. 1994; Wu et al. 1995; Vermeulen et al. 1996). Most studies have reported either a small decline or no association between BMI and FT concentration (Glass et al. 1977; Wu et al, 1995; Vermeulen et al. 1996; Ferrini \& Barrett- 
Connor, 1998) and this finding is consistent with the observation that A-diol-g concentration is not significantly associated with BMI (Vermeulen et al. 1993; Pasquali et al. 1997). Increasing BMI is associated with an increase in circulating oestrogens (Kley et al. 1980a; Zumoff et al. 1981), probably caused by the peripheral conversion of androgens to oestrogens in adipose tissue (Schneider et al. 1979; Kley et al. 1980b).

The mechanisms underlying the hormonal changes that occur with an increasing BMI are not fully understood, but the primary effect of obesity may be to cause a decrease in SHBG concentration, perhaps due to an inhibitory effect of hyperinsulinaemia on SHBG production (Pasquali et al. 1995). The reduction in SHBG then leads to an increase in the proportion of FT and a corresponding fall in testosterone production via the negative feedback mechanism to maintain FT concentration at a constant level. In severely-obese men $\left(B M I>40 \mathrm{~kg} / \mathrm{m}^{2}\right.$ ), low LH and testosterone concentrations have been reported, indicating impairment of the feedback regulation of testosterone levels (Vermeulen et al. 1993).

\section{Ethnicity}

There is some evidence to suggest that young African-American men (under 40 years of age) have higher circulating levels of testosterone than Caucasian men (Ross et al. 1986; Ellis \& Nyborg, 1992). However, such differences have not been observed in studies in older men (Hill et al. 1980; Kubricht et al. 1999), indicating that increasing age may attenuate racial differences in testosterone concentration (Ellis \& Nyborg, 1992). The evidence that Asian men of any age have lower levels of testosterone compared with Caucasian men is more inconsistent, with both associations (De Jong et al. 1991; Santer et al. 1998) and no associations being found (Lookingbill et al. 1991; Ellis \& Nyborg, 1992; Ross et al. 1992; Jin et al. 1999). Nevertheless, Caucasian and African-American men have been found to have 25-45\% higher A-diol-g concentrations compared with Asian men at young ages (Lookingbill et al. 1991; Ross et al. 1992). Furthermore, plasma ratios of DHT:testosterone (an indirect measure of tissue metabolism of testosterone to DHT and a marker of $5 \alpha$-reductase activity) have also been reported to be higher among elderly Caucasian men compared with men of Chinese or Japanese origin (Wu et al. 1995; Jin et al. 1999).

\section{Other factors}

Little is known about the relationship between other lifestyle factors and sex hormone levels. The evidence that acute alcohol intake suppresses testosterone concentration is inconsistent (Gordon et al. 1976; Ylikahri et al. 1978), although differences in dose and duration of alcohol consumption may have accounted for some of the discrepant findings (Ellingboe, 1987). Crosssectional analyses have also reported conflicting results on the association between habitual moderate alcohol intake and testosterone concentration (Dai et al. 1981; Stefanick et al. 1987; Key et al. 1990a; Field et al. 1994; Wu et al. 1995; Ferrini \& Barrett-Connor, 1998). However, long-term heavy alcohol consumption and its associated liver cirrhosis, as well as general liver failure, has been consistently associated with low testosterone concentrations (Distiller et al. 1976; Valimaki et al. 1982) and a high SHBG concentration (Bahnsen et al. 1981).

Epidemiological evidence that cigarette smoking affects circulating levels of testosterone is inconsistent (Barrett-Connor \& Khaw, 1987; Dai et al. 1988; Field et al. 1994; Wu et al. 1995; Hsieh et al. 1998). Furthermore, the mechanisms through which smoking might influence sex hormone levels remain to be elucidated (Matzkin \& Soloway, 1993). Physical and psy- 
chological stresses have been associated with a lower testosterone concentration (Krenz et al. 1972; Theorell et al. 1990; Nilsson et al. 1995). Circulating SHBG concentration is known to be affected by thyroid hormone, exogenous oestrogens, stress and hyperprolactinaemia (Rosner, 1990). Several medical conditions and/or medications used to treat conditions such as epilepsy (Duncan et al. 1999), cardiovascular disease (Sapin et al. 1992) and hypertension (Suzuki et al. 1988) have also been associated with changes in circulating sex hormone levels. However, many of these relationships have not been well established, largely due to the small number of subjects studied and the limited ability of many studies to control for possible confounding factors.

\section{Dietary effects on sex hormone levels: possible mechanisms}

The fact that severe dietary restriction has a large effect on hormone metabolism suggests that hormone levels are, to some extent, nutritionally regulated. It has therefore been suggested that less extreme changes in diet may also have physiologically significant effects on circulating sex

hormone levels. Several mechanisms have been proposed through which changes in the nutritional composition of the diet might affect hormone metabolism.

\section{The effects of severe undernutrition on circulating sex hormone levels}

It is well known that in circumstances of chronic undernutrition such as anorexia nervosa hormone metabolism is severely affected. This situation is most evident among young women, with a reduction in circulating gonadotropin and oestrogen concentrations and disruption of the menstrual cycle (Foppiani et al. 1997; Warren et al. 1999). Severe undernutrition in men also results in severe hypogonadotrophic hypogonadism, with very low concentrations of testosterone and LH (Lado-Abeal et al. 1999; Tomova \& Kumanoe, 1999).

\section{The effects of a low-fat high-fibre diet on the enterohepatic circulation of steroids}

Less extreme changes in diet may also affect circulating hormone levels through effects on the enterohepatic circulation of steroids, which plays an important role in the metabolism of sex hormones in man. Within the liver, steroids are metabolised and conjugated with $\mathrm{H}_{2} \mathrm{SO}_{4}$ and/or glucuronic acid. Approximately $20-50 \%$ of conjugated steroids are secreted into the bile and enter the small intestine; the remaining steroids are excreted in the urine. Most of the biliary conjugates (approximately 90\%) are hydrolysed by intestinal bacteria, which host hydrolytic enzymes, of which the $\beta$-glucuronidases and the sulfatases are the most important. Once steroids are hydrolysed in the intestine, approximately $80 \%$ are reabsorbed into the bloodstream and partly reconjugated in the intestinal mucosa. The conjugates that escape hydrolysis (approximately 10\%) are excreted via the faecal route. The reabsorbed steroids are passed via the portal system to the liver, where they are mostly reconjugated and re-enter the bile to repeat the enterohepatic cycle. The physiological significance of the enterohepatic circulation is not well understood, but the overall effect is a delay in the excretion of steroids, and hence an increase in plasma and urinary levels (Adlercreutz \& Martin, 1980; Adlercreutz et al. 1987; Groh et al. 1993). Dietary factors that affect gastrointestinal function, especially bacterial metabolism and the intestinal absorptive capacity, could therefore influence hormonal status. 
A low-fat high-fibre diet, characterised by a low intake of animal products and a high intake of plant foods, could in theory influence the enterohepatic circulation and reduce circulating hormone concentrations via three main mechanisms. Some types of dietary fibre (NSP) have been shown to trap or bind steroids excreted in the bile (Kay \& Strasberg, 1978; Adlercreutz et al. 1987), thereby increasing their faecal excretion and reducing enterohepatic circulation. Indeed, fibre intake in women has been found to increase faecal excretion (Goldin et al. 1982) and reduce urinary excretion of steroids (Armstrong et al. 1981; Goldin et al. 1982). However, the evidence that this results in a concomitant reduction in circulating plasma oestrogen levels is inconsistent (Barbosa et al. 1990; Rose et al. 1991; Goldin et al. 1994; Stark et al. 1998). There is some evidence that this mechanism may also affect androgen metabolism in men, because in vitro studies have found fibre (particularly water-insoluble fibre such as lignin) to bind to testosterone and DHT (Shultz \& Howie, 1986). Vegan men who have a high intake of dietary lignins have been shown to have a substantially higher faecal excretion of conjugated steroids than meat-eaters (Ross et al. 1990; Pusateri et al. 1990).

A second mechanism through which dietary fibre and resistant starch (i.e. starch that escapes hydrolysis) may interrupt hormone metabolism is via a faecal bulking effect (Shetty \& Kurpad, 1986; Birkett et al. 1997). An increase in faecal weight and moisture will decrease the transit time through the intestine and colon (Birkett et al. 1997), resulting in a greater proportion of steroids being excreted via the faecal route, rather than being reabsorbed into the enterohepatic circulation (Lewis et al. 1997).

Finally, a low-fat high-fibre diet may alter the composition of faecal bacterial flora, decreasing $\beta$-glucuronidase activity in the intestine. This process will result in reduced reabsorption of unconjugated steroid hormones into the bloodstream (Goldin \& Gorbach, 1976; Järvenpää et al. 1980; Reddy et al. 1980). However, other experimental studies have not found diet to influence faecal bacterial activity (Cummings et al. 1978; Goldin et al. 1980) and the variation in type and dose of fibre, as well as experimental design, makes interpretation of these studies difficult.

\section{The effects of a low-fat high-fibre diet on circulating insulin levels}

Alternatively, it has been hypothesised that a low-fat high-fibre diet might indirectly increase serum androgen levels, by preventing the development of insulin resistance (Smith, 1994), which is associated with reduced levels of SHBG (Haffner et al. 1994; Pasquali et al. 1995). High amounts of dietary fibre (particularly pectin) and resistant starch reduce the rate of glucose absorption in the intestine, thereby increasing net glucagon concentration, reducing insulin levels and enhancing insulin sensitivity (Jenkins et al. 1978). Indeed, reductions in glucose and insulin levels have been observed following a diet high in dietary fibre (Anderson et al. 1995; Thorsdottir et al. 1998). Lower insulin levels might lead to an increase in SHBG production, as insulin has been demonstrated to directly inhibit SHBG secretion in vitro (Plymate et al. 1988). Insulin is also inversely correlated with SHBG concentrations among both normal-weight and obese men (Strain et al. 1994; Pasquali et al. 1995; Vermeulen et al. 1996). Indeed, the inhibitory effect of hyperinsulinaemia on SHBG concentration appears to occur irrespective of an individual's BMI (Lazarus et al. 1998). In accordance with this finding, cross-sectional data from normal-weight and obese men show that insulin levels are also negatively correlated with testosterone concentrations (Haffner, 1996; Tchernof et al. 1997). As such, lower insulin levels may be associated with higher testosterone levels due to an increase in SHBG production. 


\section{The effects of fat on circulating sex hormone levels}

It has been widely suggested that animal fat, which is rich in saturated fatty acids, may increase concentrations of circulating sex hormones by directly influencing androgen production and/or metabolism. However, there is no compelling biological mechanism for such an effect. In fact, the hypothesis that fat may increase androgen levels has been largely derived from broad ecological observations that fat consumption appears to parallel rates of prostate cancer incidence (Rose et al. 1986; Yu et al. 1991), together with the theory that high androgen levels increase the risk for prostate cancer (Gann et al. 1996).

Some experimental evidence suggested that high concentrations of polyunsaturated fatty acids might influence circulating levels of bioavailable steroids by reducing the binding of testosterone (Martin et al. 1986; Reed et al. 1986) and oestradiol to SHBG (Bruning \& Bonfrer, 1986; Reed et al. 1986). However, such an effect has not been observed at physiological concentrations (Diver, 1993) and an in vivo study did not find a strong relationship between free fatty acid concentration and the percentage free hormone concentration in women (Key et al. $1990 b$ ).

\section{The effects of dietary phyto-oestrogens on circulating sex hormone levels}

Isoflavones and lignans are two groups of diphenolic compounds (generically named phytooestrogens) that are widely distributed in plants. They have structural similarities with oestradiol and have been implicated in altering sex hormone metabolism via several mechanisms. Soyabean products are the primary food source of the isoflavone glycosides genistin and daidzin, which are metabolised by colonic microflora to the biologically-active aglycones, genistein and daidzein. Daidzein can be further metabolised to equol and $O$-desmethylangolensin (Setchell, 1998), all of which have oestrogenic activity. Flaxseed and fibre-rich foods such as bran, whole cereals and legumes are the most abundant source of the mammalian lignan precursors, matairesinol and secoisolariciresinol (Thompson et al. 1991). These compounds are metabolised by bacteria in the intestinal tract to enterolactone and enterodiol respectively (Lampe et al. 1994).

The majority of the phyto-oestrogen precursor compounds are hydrolysed by intestinal bacteria, and the aglycones and their metabolites are absorbed into the bloodstream to undergo enterohepatic circulation in a similar fashion to endogenous steroid hormones (Adlercreutz et al. 1987). A daily intake of $25-100 \mathrm{mg}$ isoflavones, which is typical of that consumed in Asian countries (Barnes et al. 1995) or in some vegetarian and vegan diets (Adlercreutz et al. 1993) is thought to be high enough to elicit a physiological response (Adlercreutz \& Mazur, 1997). However, there is considerable inter-individual variation in isoflavone excretion following consumption of soyabean foods (Hutchins et al. 1995). The conversion of daidzein to equol by intestinal microbes only occurs in approximately $30 \%$ of the population (Hutchins et al. 1995), although a high-carbohydrate low-fat diet (Bowey et al. 1988) and chronic soyabean ingestion may increase this conversion rate ( $\mathrm{Lu}$ et al. 1995). Such dietary differences in the intestinal bacterial environment may be of importance, as these compounds vary greatly in their potency, ranging from $1 / 500$ to $1 / 1000$ of the activity of oestradiol, with equol being much more potent than $O$-desmethylangolensin (Markiewicz et al. 1993; Sathyamoorthy et al. 1994).

Isoflavones and lignans were originally believed to influence hormone metabolism due to their ability to bind to the oestrogen receptor in cells, to block the action of the more potent oestrogens, and hence exert anti-oestrogenic and anti-gonadotrophic effects (Adlercreutz et al. 1992; Markiewicz et al. 1993). However, these compounds may also affect steroid metabolism 
via other mechanisms. In vitro studies suggest phyto-oestrogens can directly increase hepatic SHBG synthesis (Adlercreutz et al. 1992; Mousavi \& Adlercreutz, 1993; Loukovaara et al. 1995), thereby potentially reducing the availability of testosterone to enter target cells and elicit a biological response. Phyto-oestrogens may also have enzyme-inhibitory effects; of particular interest is the ability of the isoflavone genistein to inhibit $17 \beta$-hydroxysteroid dehydrogenase, $5 \alpha$-reductase and aromatase (Adlercreutz et al. 1992; Evans et al. 1995; Pelissero et al. 1996). Reduced activity of these enzymes could hypothetically lead to lower levels of plasma androgens and oestrogens, and lower levels of DHT in androgen target cells, but the relevance of these effects at physiological concentrations in human subjects has not been established.

\section{Studies of diet and hormone levels in men}

\section{Intervention studies}

Several studies have investigated the effects of different dietary regimens on endogenous hormone levels in men. For the present review, we identified studies through a search of the Medline $^{\mathbb{R}}$ database for literature on sex hormones and dietary intervention studies, written in the English language. Such studies have generally focused on differences in total dietary fat and/or dietary fibre intake on circulating hormone levels. The investigation of the hormonal effects of phyto-oestrogens in men is still in its infancy, although a few small studies have been published (mostly in abstract form).

Changes in dietary fat and/or dietary fibre intake Table 1 summarises the dietary intervention studies that have focused on the effect of changes in dietary fat and/or dietary fibre consumption on endogenous hormone levels. Typically, study subjects who ate a Western diet (approximately $40 \%$ energy from fat) were given a low-fat diet (less than $25 \%$ energy from fat) or vice versa over a period of a few weeks in a controlled setting. Individualised meals or menus were prepared to maintain body weight throughout the intervention period (unless on a weight-reducing diet; Rosenthal et al. 1985). In most studies there was no control group, and baseline hormone levels were compared with measurements obtained after the period of dietary intervention.

Despite the relatively short study periods, these dietary regimens may be sufficient to elicit physiological changes as they involve large changes in fat intake of $>15 \%$ of total energy. The first dietary intervention study was conducted using twenty-four North American white and black men given a low-fat diet, and twenty black South African men given a high-fat 'Western' diet, for 3 weeks. A large reduction in total fat (from 40 to $25 \%$ energy intake) was associated with a significant fall in plasma cholesterol concentration among the black Americans, and significant reductions in plasma testosterone concentration in both the black and white Americans (Hill et al. 1980). Although the change to a Western diet was associated with a significant increase in cholesterol concentration in the black South African men, it was also associated with a significant fall in testosterone concentration (Hill et al. 1980), an observation that was repeated in a later study (Hill et al. 1982). Neither study found oestradiol concentration to be significantly affected by diet, although oestrone concentration was substantially higher following the high-fat regimen (Hill et al. 1982).

A study conducted in thirty white Finnish men found a low-fat diet (resulting in a change from 40 to $25 \%$ energy intake from fat) to be associated with significantly $(P<0 \cdot 01)$ reduced testosterone and FT concentrations after 6 weeks (Hämäläinen et al. 1984). DHT, SHBG and oestradiol concentrations also declined, but these changes were not statistically significant. 

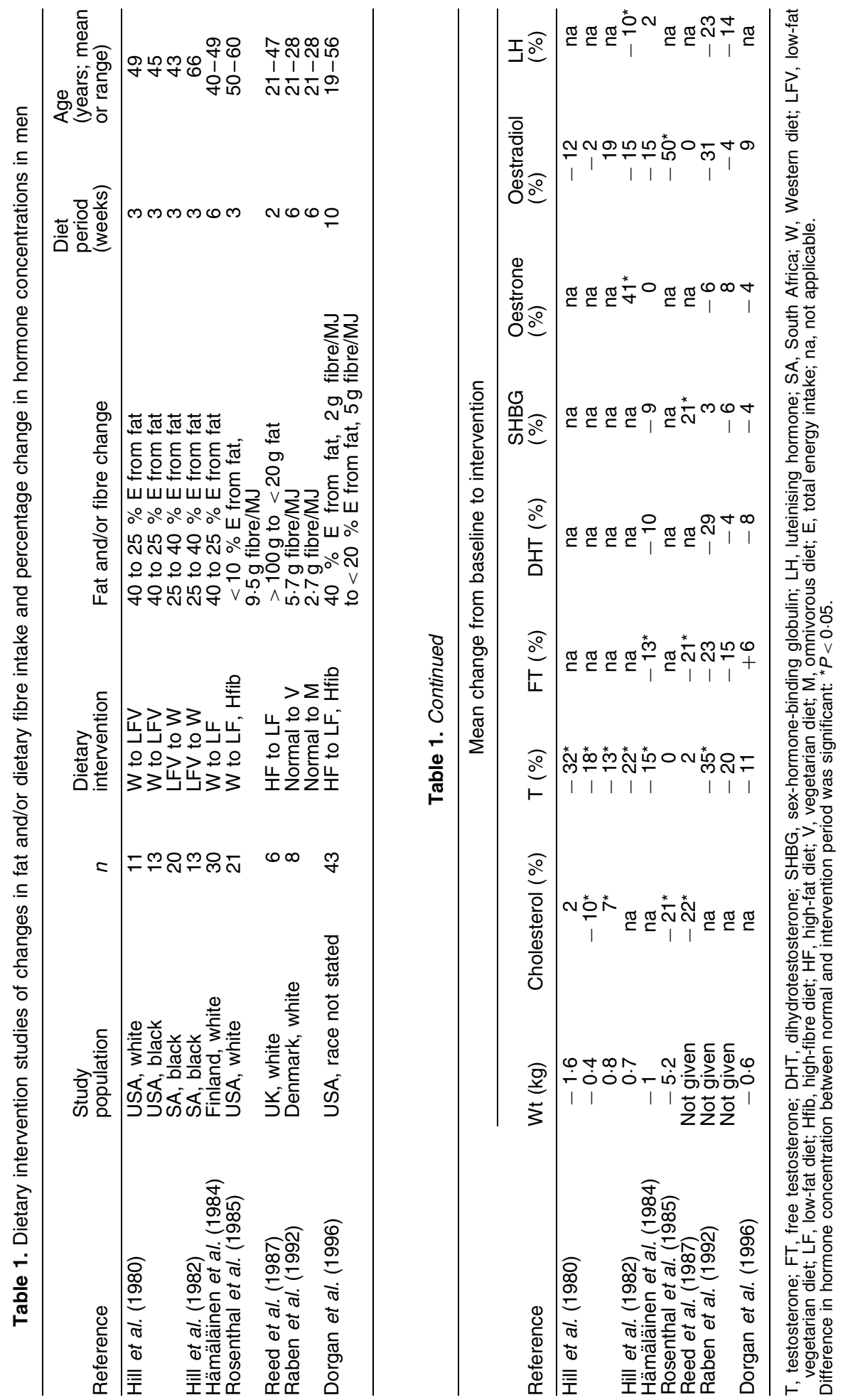
A diet extremely low in fat and high in dietary fibre given to obese men in hospital was associated with a significant reduction in plasma cholesterol concentration $(P<0 \cdot 01)$, no change in testosterone concentration, and a $50 \%$ reduction in oestradiol concentration (Rosenthal et al. 1985). However, because the weight of the subjects was significantly reduced $(P<0.01)$ by an average of $5 \mathrm{~kg}$ during the 3 -week intervention period, changes in hormone levels in this study must be interpreted with caution. In particular, a loss of fat may have contributed to the rapid reduction in oestradiol concentration. Furthermore, many of these hospitalised subjects had medical conditions and/or were receiving medications that are known to influence steroid hormones (such as anti-hypertensive drugs and insulin for diabetes). These subjects were also enrolled in an exercise programme during the intervention period, making it impossible to attribute the hormonal changes observed to the dietary change.

Reed et al. (1987) examined the effects of a low-fat diet by comparing the differences in sex hormone levels after changing from a high-fat diet (more than $100 \mathrm{~g}$ fat/d) to a very low-fat diet (less than $20 \mathrm{~g}$ fat/d) in six men. As predicted, there was a significant reduction $(P<0 \cdot 01)$ in cholesterol concentration when on the low-fat diet, even after an intervention period of only 2 weeks. SHBG concentration was also significantly elevated $(P<0.001)$, and FT concentration declined correspondingly. There were no reported differences in testosterone or oestradiol concentrations. However, due to the small number of study subjects, these results should be interpreted with caution.

One study investigated the effects of a change from a high-meat diet to a lacto-ovovegetarian diet, whilst maintaining the same energy and overall fat intake, on sex hormone levels in eight men (Raben et al. 1992). This study incorporated a cross-over design, whereby participants were separated into two groups at the start of each diet. After 6 weeks on one diet, subjects were given a 4-week wash-out period on their habitual diet and then switched over to the other diet. Mean testosterone concentration declined significantly $(P<0.001)$ by $35 \%$ after 6 weeks on the vegetarian diet compared with baseline values, and although testosterone also declined on the meat diet, it was not significantly different from initial values. FT, DHT, oestradiol and LH concentrations were also not significantly different on either diet. The subjects were young elite endurance athletes whose hormonal profile may well be different from that of the predominantly middle-aged men recruited in the other studies.

One study implemented a randomised cross-over design whereby subjects were matched by age, BMI and smoking status and randomly assigned either to the low-fat high-fibre diet or the high-fat low-fibre diet, before crossing over to the other diet (Dorgan et al. 1996). The dietary effect was assessed by comparing the differences in hormone levels between the two dietary regimens. This study had more power than the other studies to discern small effects due to a larger number of study subjects $(n 43)$. There were no substantial differences in the circulating concentrations of testosterone, FT, DHT, SHBG, oestrogens or LH in men when transferred from a high-fat low-fibre diet to a low-fat high-fibre diet for 10 weeks (Dorgan et al. 1996).

These dietary intervention studies have not established the effects, if any, of dietary fat and/or fibre intake on circulating sex hormone concentrations. In general, they have shown that, as expected, cholesterol concentration was elevated following a high-fat low-fibre diet, and reduced on a low-fat high-fibre diet, but the reported changes in sex hormone levels following dietary intervention were inconsistent. Testosterone concentration was found to be reduced following change to both a high-fat low-fibre diet and a low-fat high-fibre diet, and most of the studies have failed to observe any association between a low-fat high-fibre diet and concentrations of other sex hormones or SHBG. The high inter-correlation of nutrient intakes, the short intervention periods and the small numbers of subjects in all these studies, coupled with 

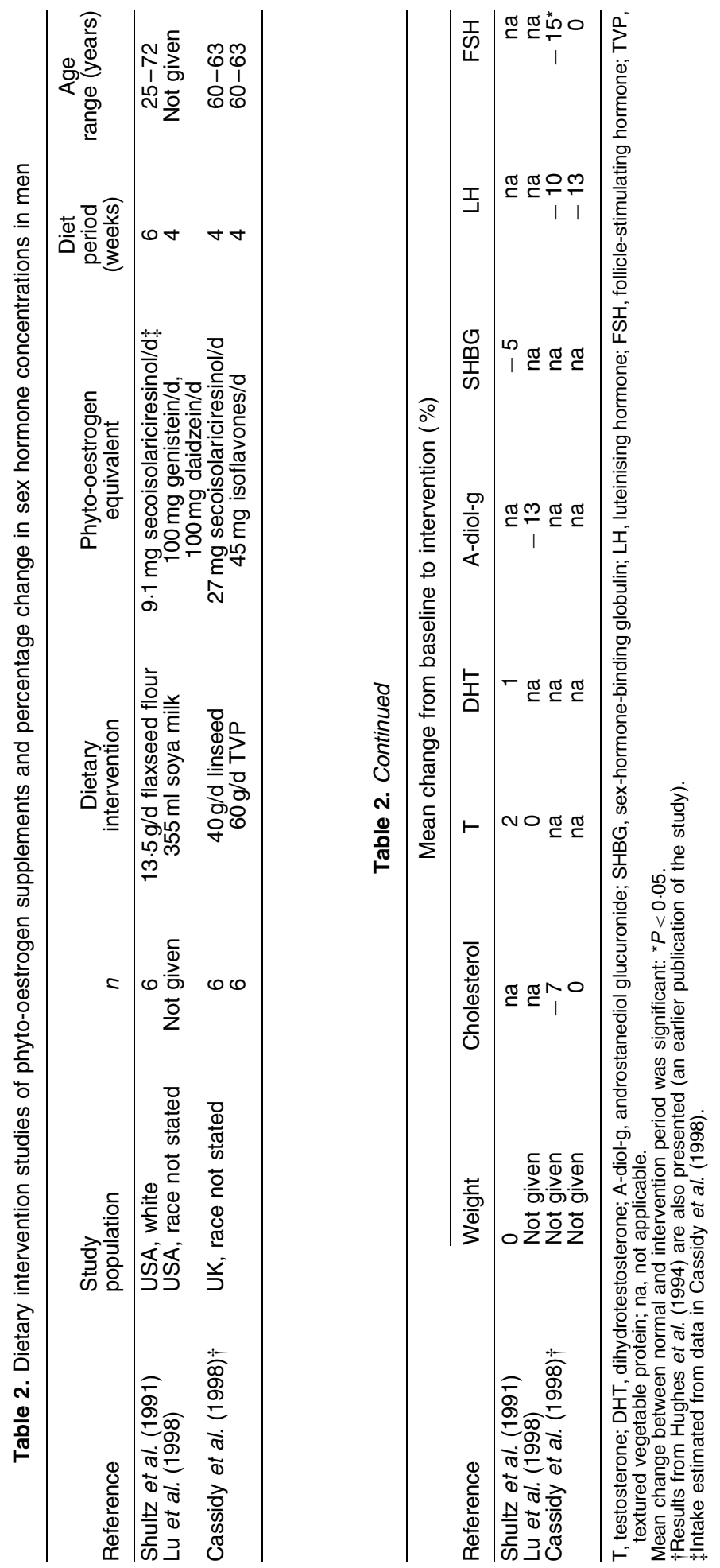
the lack of control groups in most studies, reduced the ability to detect differences in hormone levels that could be attributable to dietary change.

Changes in phyto-oestrogen intake There are very few data regarding the effects of phytooestrogens on circulating sex hormone levels in men, and the studies to date have included very small numbers of subjects with limited information on hormonal change following phytooestrogen consumption (Table 2). Lignan supplementation, in the form of six slices of flaxseed bread per d for 6 weeks, was found to have no effect on circulating testosterone, FT or SHBG concentrations in six men (Shultz et al. 1991). Soyabean consumption in the form of $355 \mathrm{ml}$ soya milk supplementation for 4 weeks also had no effect on serum testosterone concentration, although there was a non-significant $13 \%$ decrease in A-diol-g concentration compared with pre-soyabean diet values (Lu et al. 1998). A similar study investigated the effects of foods containing both isoflavones and lignans on gonadotrophin levels in six elderly men (Cassidy et al. 1998): $40 \mathrm{~g}$ linseed/d was associated with a $10 \%$ reduction in $\mathrm{LH}$ concentration and a significant $(P<0.05) 15 \%$ reduction in follicle-stimulating hormone concentration; $60 \mathrm{~g}$ textured vegetable protein/d was also associated with a $13 \%$ reduction in $\mathrm{LH}$, but the change in follicle-stimulating hormone concentration was negligible (Cassidy et al. 1998).

The current data on dietary intervention studies of phyto-oestrogens and sex hormone levels in men are too scanty to interpret with confidence. Although much more research has been done in women due to the potential anti-oestrogenic effects of phyto-oestrogens, the evidence for an effect on sex hormones and/or SHBG concentrations still remains weak and inconsistent (Phipps et al. 1993; Baird et al. 1995; Lu et al. 1996; Brzezinski et al. 1997). As with the dietary fat intervention studies, interpretation is hampered by the small numbers of study subjects and lack of control groups. Confounding may also be a problem due to the parallel ingestion of dietary fibre and soyabean protein, which could have independent effects on hormone levels. The short intervention periods and the probable inclusion of individuals with varying habitual diets makes interpretation of the effects of phyto-oestrogens on sex hormone levels very difficult. This situation is a result of gut-flora composition, which has an important role in the metabolism of phyto-oestrogens, and is largely a result of long-term dietary habits.

\section{Observational studies}

\section{Associations between nutrient intake and circulating hormone levels: correlational analyses}

A small number of cross-sectional studies have investigated the relationship between dietary intake and circulating sex hormones in men. Although nutrients have been observed to be more weakly associated with hormone levels than factors such as age and BMI, several statistically significant associations have been reported. Bishop et al. (1988) examined the association of diet with circulating hormone levels while controlling for genetic factors by analysing the differences in hormone levels according to the variation in dietary intake between 155 monozygotic twin pairs. As expected, weight and BMI were the strongest determinants of hormone levels, although fat intake was significantly positively associated with A-diol-g concentration (Spearman correlation coefficient, $r$ 0.26), $\mathrm{Zn}$ and protein were negatively associated with FT concentration $(r-0.22$ and -0.25 respectively) and crude fibre was positively associated with SHBG concentration $(r$ 0.26). These associations were not adjusted for BMI. 
The relationships between lifestyle factors and dietary intake and sex hormone levels were also investigated in a random sample of 1241 middle-aged US men (Field et al. 1994). After adjustment for multiple potential confounders, A-diol-g concentration was found to be significantly negatively correlated with protein and crude fibre intake (Pearson's partial correlation coefficients, $r-0.10$ and -0.06 respectively) and positively correlated with alcohol intake $(r$ $0 \cdot 08)$. SHBG concentration was positively correlated with crude and dietary fibre $(r 0.08)$, and negatively correlated with animal fat $(r-0 \cdot 06)$. No nutrients were associated with testosterone or FT concentrations. A study among forty male meat-eaters and vegans also found that no nutrients were correlated with testosterone or FT concentrations after multiple adjustment for age, BMI and diet group (Key et al. 1990a). However, SHBG concentration was significantly positively correlated with total fat, saturated and polyunsaturated fatty acids (Pearson's partial correlation coefficients, $r>0 \cdot 35$ ), but not with dietary fibre (Key et al. 1990a). In contrast, a cross-sectional analysis of 1563 middle-aged US men found no association between fat intake and SHBG concentration, but found protein intake to be negatively correlated with SHBG and dietary fibre intake to be positively correlated with SHBG after multiple adjustment for lifestyle factors and other hormones (Longcope et al. 2000).

The reasons for the inconsistencies between these studies may partly be due to confounding factors that were not accounted for in some of the analyses. The lack of variability in nutrient intake in most of these studies is also likely to limit their power to detect small associations. Finally, some of these associations are likely to be a result of chance due to the large number of significance tests performed.

\section{Differences in serum hormone levels between meat-eaters, vegetarians and vegans}

To date, six studies have compared circulating hormone levels between long-standing meateaters, vegetarians and/or vegans, in another approach to identifying the effects of diet on hormone metabolism at a population level. These studies have some advantages over intervention trials in that they can more easily include large numbers, and the period of dietary exposure is usually much longer. However, dietary intakes are usually not as extreme as those provided in the intervention studies. Any physiological effects of diet on circulating hormone levels might be expected to be more pronounced between meat-eaters and vegans, rather than between meat-eaters and lacto-ovo-vegetarians.

Differences in macronutrient intake between meat-eaters, vegetarians and vegans in these six studies are shown in Table 3. In order to make nutrient intakes more easily comparable between dietary groups, nutrient densities (intake as a percentage of energy or per MJ) are presented along with absolute intakes. Vegetarian diets can vary quite widely, but are usually lower in saturated fatty acids, contributing between 5 and $10 \%$ total energy, compared with a predominantly meat-eating diet (10-15\% energy). Conversely, intake of polyunsaturated fatty acids is higher among vegetarians, and in particular among vegans, contributing 8-10\% energy, compared with meat-eaters (4-7\% energy; Key et al. 1990a; Allen et al. 2000). Nevertheless, total fat intake as a percentage of energy is generally similar between meat-eaters and non meat-eaters (contributing 30-40\% energy in all dietary groups). As such, the main hypothesis addressed by the intervention studies, that total fat intake is related to hormone levels, cannot be adequately addressed. Both lacto-ovo-vegetarian and vegan diets are lower in protein and cholesterol, and higher in carbohydrate and dietary fibre than a diet including regular meat consumption. Furthermore, the protein bioavailability is reduced by approximately $10 \%$ on a vegetarian fibre-rich diet (World Health Organization, 1985). Non-meat- 
The effects of diet on sex hormone levels in men

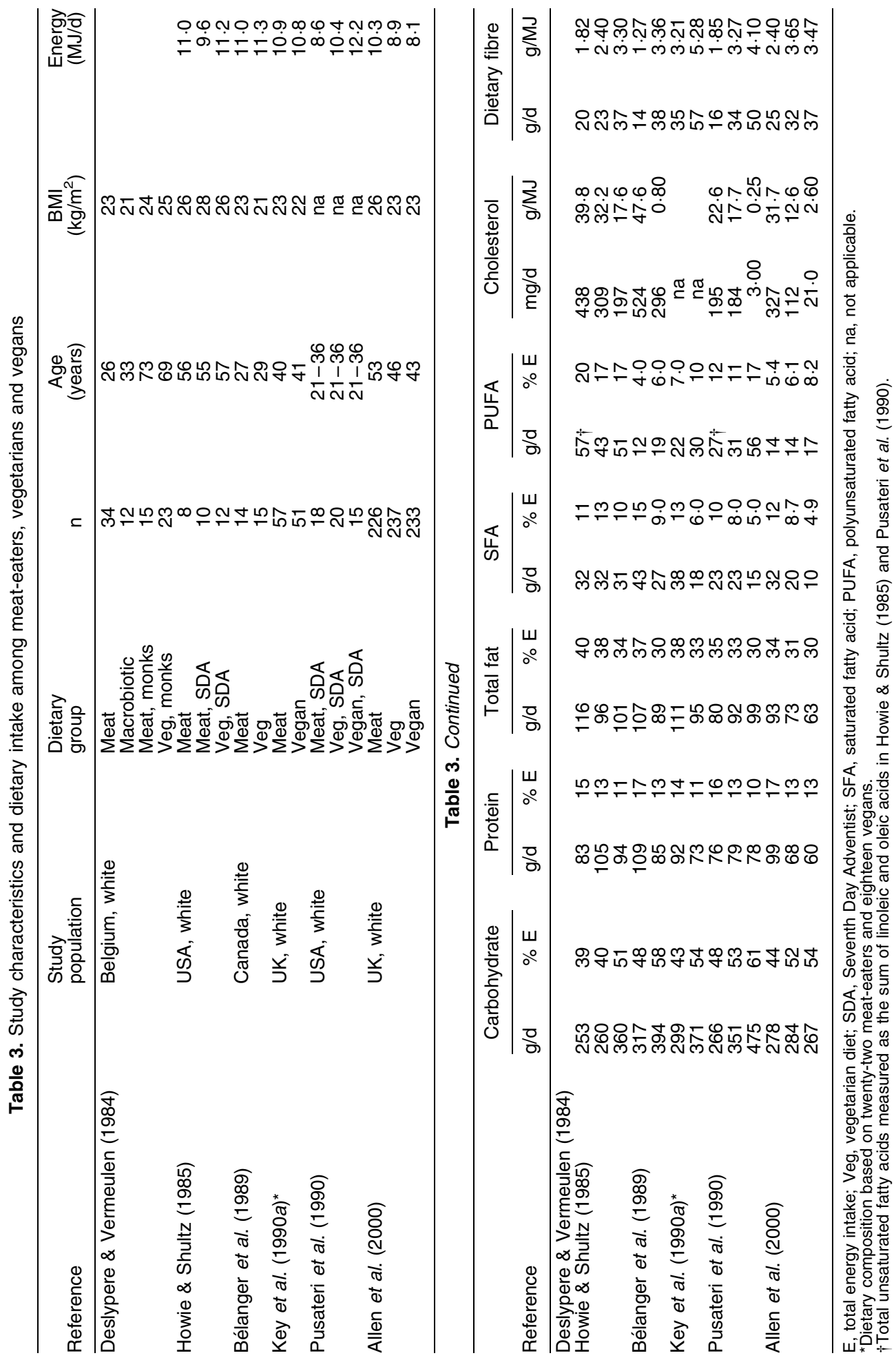


eaters will also tend to have a higher intake of dietary phyto-oestrogens than meat-eaters due to higher consumption of soyabean, other legumes and unrefined plant foods (Adlercreutz et al. 1993). However, accurate data on intakes of phyto-oestrogens are limited.

Differences in serum hormone concentrations between meat-eaters, vegetarians and vegans in these studies are shown in Table 4. Vegans have been observed to have a significantly higher mean SHBG concentration than meat-eaters; this difference is partly due to differences in BMI between the groups, but even after adjusting for this, vegans are found to have $11-19 \%$ higher SHBG concentrations than meat-eaters $(P<0 \cdot 05$; Key et al. 1990a; Allen et al. 2000). SHBG concentration has also been reported to be significantly higher in vegetarians compared with meat-eaters $(P<0 \cdot 05$; Bélanger et al. 1989), although the substantially lower BMI among these vegetarians may have accounted for these findings. A larger study, which accounted for the differences in BMI between diet groups, found no difference in mean SHBG between vegetarians and meat-eaters (Allen et al. 2000).

Concomitant with an increase in SHBG concentration among vegans compared with meateaters is the small increase in testosterone concentration (Key et al. 1990a; Pusateri et al. 1990; Allen et al. 2000), although Allen et al. (2000) was the only study large enough to detect significant differences $(P<0 \cdot 05)$. One small study reported no differences in testosterone concentration between dietary groups (Deslypere \& Vermeulen, 1984), and another found Seventh Day Adventist (SDA) vegetarians to have a lower mean testosterone concentration than non-Seventh Day Adventist meat-eaters $(P<0.05)$; the fact that they were not significantly different to SDA meat-eaters, however, suggests that factors relating to other lifestyle characteristics may account for this difference (Howie \& Shultz, 1985).

There is generally consistent evidence to suggest that circulating concentrations of FT, DHT and A-diol-g are similar between dietary groups (Deslypere \& Vermeulen, 1984; Howie \& Shultz, 1985; Key et al. 1990a; Allen et al. 2000). The only exception to these findings is the significantly lower A-diol-g concentration among vegetarians compared with meat-eaters $(P<0.05)$ in the small study of Bélanger et al. (1989). As mentioned previously, these results should be interpreted with caution due to the potential confounding effect of BMI.

One early study reported a significantly lower oestradiol concentration in vegetarians compared with meat-eaters $(P<0.05$; Howie \& Shultz, 1985). Other studies, however, have not substantiated this finding (Deslypere \& Vermeulen, 1984; Bélanger et al. 1989; Key et al. 1990a; Pusateri et al. 1990) Similarly, no differences in LH concentration have been reported between meat-eaters, vegetarians and vegans (Deslypere \& Vermeulen, 1984; Howie \& Shultz, 1985; Allen et al. 2000).

There is evidence that circulating SHBG concentration is higher in vegans than meateaters, even after accounting for the differences in BMI between dietary groups. Identification of the nutritional characteristics of a vegan diet that may increase SHBG concentration is difficult; the effects of diet on SHBG could involve several inter-related underlying mechanisms, aside from the diet-related change in body composition. As mentioned previously, these mechanisms may involve the effects of decreased fat and increased fibre, phyto-oestrogens and/ or greater insulin sensitivity. Dietary fibre has been most consistently positively correlated with SHBG in correlational analyses (Bishop et al. 1988; Field et al. 1994; Longcope et al. 2000), although Key et al. (1990a) reported no association. However, the fibre intake was high even among the meat-eaters in this latter study (Table 3) which might mask a correlation over a broader range of fibre intakes. The relationship between fat intake and SHBG concentration has been more inconsistent, with negative (Field et al. 1994), positive (Key et al. 1990a) and no associations being reported (Bishop et al. 1988; Longcope et al. 2000). There are, as yet, no cross-sectional data which have examined the association between phyto-oestrogen con- 
The effects of diet on sex hormone levels in men

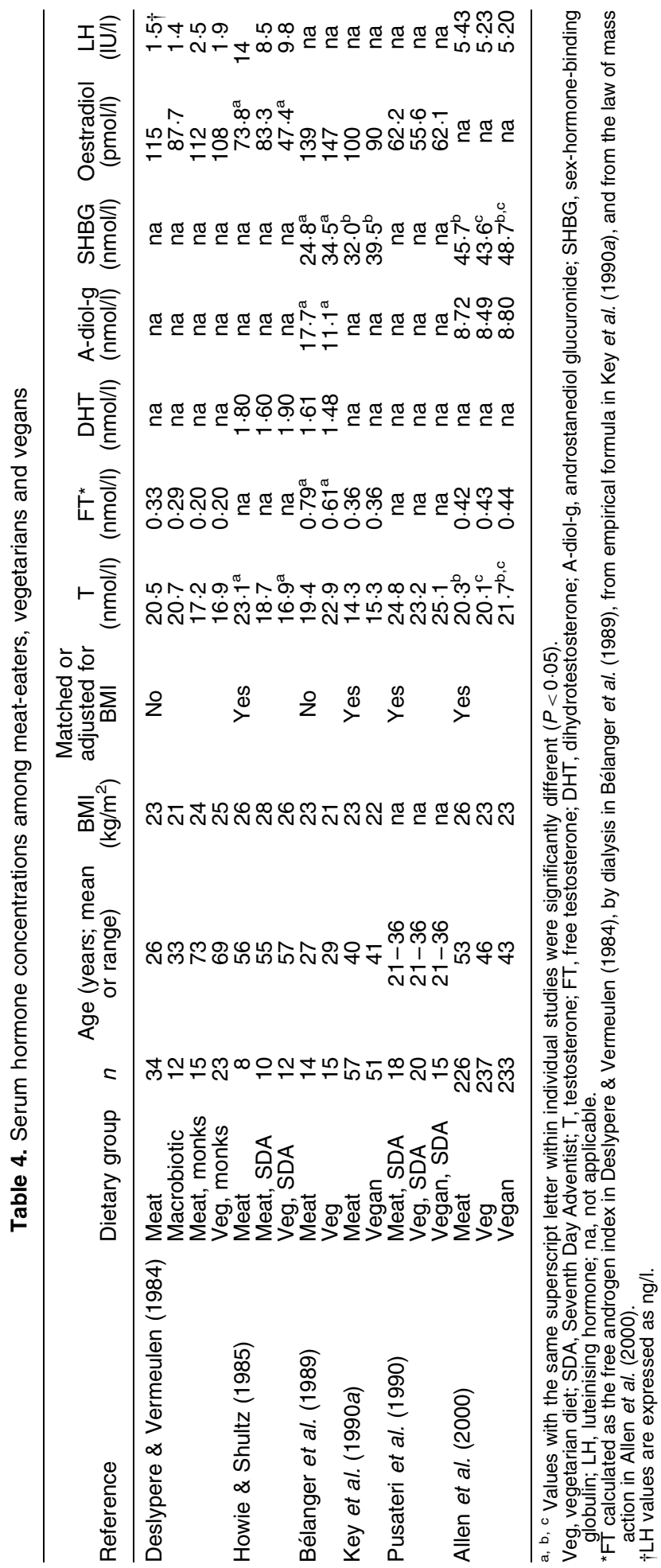


sumption and SHBG concentration in men. The only study in women found no association with soyabean intake (Nagata et al. 1997).

A plausible explanation for the higher testosterone concentration observed in vegans is that an increase in SHBG causes an increase in testosterone in order to maintain a constant FT concentration (Dunn et al. 1981). This interpretation is substantiated by the similar concentrations of bioavailable androgens, as measured by FT, DHT and A-diol-g concentrations, observed among meat-eaters, vegetarians and vegans.

\section{General discussion}

There is considerable epidemiological evidence that a Western-style diet may increase the risk of certain hormone-dependent diseases via its effects on hormone metabolism (Giles \& Ireland, 1997; Denis et al. 1999). However, the mechanisms through which diet may influence circulating hormone concentrations in men are not well understood. In comparison with factors such as age and BMI, nutrients do not appear to be strong determinants of hormone levels. However, there is experimental evidence to suggest that dietary factors may exert subtle effects on hormone metabolism which, although difficult to detect in small epidemiological studies, may be sufficient to exert physiological effects.

There is little evidence from intervention studies that diet is related to serum androgen levels, with changes to both low-fat and high-fat diets having been reported to reduce testosterone, FT and DHT concentrations over the short-term. Data from observational studies do not support the hypothesis that a diet low in saturated fatty acids is associated with lower androgen concentrations. Indeed, there is a tendency for testosterone levels to be slightly higher among vegans than meat-eaters, most probably as a direct response to an elevated SHBG concentration. A vegetarian and/or low-fat diet also has not been shown to influence LH levels, further implying that effects on androgens are insufficient to provoke a gonadotrophic response. Given the absence of clear effects of diet on androgens, the lack of dietary effect on oestrogens would be expected because circulating oestrone and oestradiol in men are largely derived from peripheral conversion of androgens. One explanation as to why diet does not appear to elicit substantial differences in circulating androgen levels is due to the body's natural feedback mechanism to maintain the internal environment. Indeed, the small increase in testosterone concentration observed among vegan men is almost certainly caused by the increase in SHBG, in order to maintain a constant level of FT.

Little work has been done on the effects of phyto-oestrogens in men. The increase in SHBG concentration observed in vegans compared with meat-eaters could to some extent be due to their consumption of phyto-oestrogens. However, larger studies are needed to have sufficient power to determine whether phyto-oestrogens modulate SHBG levels in vivo. The $13 \%$ reduction in A-diol-g observed following dietary supplementation of isoflavones (Lu et al. 1998 ) is consistent with the experimental evidence that phyto-oestrogens may inhibit $5 \alpha-$ reductase activity (Evans et al. 1995). However, in a much larger study, vegetarian and vegan men who were known to consume soyabean regularly were not found to have lower A-diol-g levels than meat-eaters (Allen et al. 2000). It may be that soyabean consumption among Western vegetarians is not sufficient to exert physiological effects.

\section{Methodological issues}

Measuring diet based on self-recall and food-frequency questionnaires will almost certainly contain some degree of measurement error. Such random misclassification of dietary exposure 
will reduce the ability to detect small associations between diet and circulating hormone levels. Although this factor is not likely to affect short-term intervention studies and observational data between dietary groups, it could be of importance when investigating the association between nutrient intakes and hormone levels in correlation studies.

Most epidemiological studies on hormones have taken blood measurements from a single sample for each individual, because the collection and storage of multiple blood samples is both difficult and expensive. Due to the known circadian variation of adrenal and gonadal steroid concentrations within individuals (Goldman et al. 1985; Cooke et al. 1993), the majority of studies have ensured that all blood samples were taken at the same time of day. A single measurement of circulating serum testosterone and DHT concentrations has been shown to reflect mean annual androgen concentrations in middle-aged men reliably, with a Pearson's correlation coefficient of 0.85 between the first sample and the mean of seven subsequent samples taken over a 1-year period (Vermeulen \& Verdonck, 1992). The within-subject variation of testosterone and SHBG measurements taken from men over a 12-month period have been reported to be substantially less than the between-subject variability (Valero-Politi \& Fuentes-Arderiu, 1993). Little is known about the long-term reliability of a single serum measurement for other hormones.

Most research has been based on the assumption that the critical exposure period for evaluating the effect of diet on hormone levels is current dietary intake. Indeed, dietary intervention studies measure hormone concentrations a few weeks after dietary change. However, dietary intake during early childhood or adolescence, when the influence of hormones may be particularly important in male sexual development, may be a more important determinant of adult circulating hormone levels. Suggestions have also been made that exposure to high concentrations of androgens in utero among the black African-American population might predispose male offspring to an increased steroid hormone secretion and/or to an increased sensitivity to the effects of testosterone in adulthood (Henderson et al. 1988). However, to our knowledge, there has been no research into the effect of early nutritional experiences in relation to adult circulating hormones in man.

\section{Conclusion}

Circulating sex hormone levels in men are strongly related to age and BMI. Increasing age is associated with a small decline in testosterone concentration, a substantial increase in SHBG concentration, and a large decline in FT concentration. An increase in BMI is associated with a substantial fall in the concentrations of testosterone and SHBG, but FT remains constant, except in severe obesity.

In comparison with these factors, the effects of diet on circulating sex hormone levels appear to be small. There is little evidence from dietary intervention studies to support the hypothesis that a change from a high-fat low-fibre diet to a low-fat high-fibre diet is associated with lower androgen levels and a higher SHBG concentration. The data on phyto-oestrogen supplements and their effects on endogenous hormone levels are, to date, too sparse for conclusions to be drawn. The findings from cross-sectional analyses of dietary intake and hormone levels have been inconsistent, although there is a suggestion that dietary fibre may be associated with higher SHBG levels. Observational studies between different dietary groups have shown that a vegan diet is associated with a small but significant increase in SHBG concentration. This increase is associated with a corresponding small increase in testosterone concentration, resulting in no alteration in the level of biologically-available testosterone. 
In conclusion, the data available have not demonstrated that variations in dietary composition have any long-term important effects on circulating sex hormone levels in men. This lack of effect may be partly explained by the efficient homeostatic control of bioavailable testosterone by negative feedback, which can readily adjust testosterone production to compensate for changes in binding by SHBG or clearance through the liver. It therefore appears that future studies should look for dietary effects on the feedback mechanism itself, perhaps by phyto-oestrogens, or on the metabolism of androgens within the target tissue.

\section{References}

Adlercreutz H, Höckerstedt K, Bannwart C, Bloigu S, Hämäläinen E, Fotsis T \& Ollus A (1987) Effect of dietary components, including lignans and phytoestrogens on enterohepatic circulation and liver metabolism of estrogens and on sex hormone-binding globulin (SHBG). Journal of Steroid Biochemistry 27, 1135-1144.

Adlercreutz H, Markkanen H \& Watanabe S (1993) Plasma concentrations of phytoestrogens in Japanese men. Lancet 342, 1209-1210.

Adlercreutz H \& Martin F (1980) Biliary excretion and intestinal metabolism of progesterone and estrogens in man. Journal of Steroid Biochemistry 13, 231-244.

Adlercreutz H \& Mazur W (1997) Phyto-estrogens and Western diseases. Annals of Medicine 29, 95-120.

Adlercreutz H, Mousavi Y, Clark J, Höckerstedt K, Hämäläinen E, Wahala K, Mäkelä T \& Hase T (1992) Dietary phytoestrogens and cancer: in vitro and in vivo studies. Journal of Steroid Biochemistry and Metabolism 41, 331337.

Allen NE, Appleby PN, Davey GK \& Key TJ (2000) Hormones and diet: low insulin-like growth factor but normal bioavailable androgens in vegan men. British Journal of Cancer 83, 95-97.

Anderson JW, O’Neal DS, Ridell-Mason S, Floore TL, Dillon DW \& Oeltgen PR (1995) Postprandial serum glucose, insulin and lipoprotein responses to high- and low-fibre diets. Metabolism 44, 848-854.

Armstrong BK, Brown JB, Clarke HT, Crooke DK, Hahnel R, Masarei JR \& Ratajczak T (1981) Diet and reproductive hormones: a study of vegetarian and non-vegetarian postmenopasual women. Journal of the National Cancer Institute 67, 761-767.

Bahnsen M, Gluud C, Johnsen SG, Bennett P, Svenstrup S, Micic S, Dietrichson O, Svendsen LB \& Brodthagen UA (1981) Pituitary-testicular function in patients with alcoholic cirrhosis of the liver. European Journal of Clinical Investigation 11, 473-479.

Baird DD, Umbach DM, Landsell L, Hughes CL, Setchell KDR, Weinberg CR, Habey AF, Wilcox AJ \& McLachlan JA (1995) Dietary intervention study to assess estrogenicity of dietary soy among postmenopausal women. Journal of Clinical Endocrinology and Metabolism 80, 1685-1690.

Ball M (1997) Vegetarian, vegan or meat-eater: the pros and cons. Australian Family Physician 26, $1269-1274$.

Barbosa JC, Shultz TD, Filley SJ \& Neiman DC (1990) The relationship among adiposity, diet and hormone concentrations in vegetarian and non-vegetarian postmenopausal women. American Journal of Clinical Nutrition 51, 798-803.

Barnes S, Peterson G \& Coward L (1995) Rationale for the use of genistein-containing soy matrices in chemoprevention trials for breast and prostate cancer. Journal of Cellular Biochemistry 22, Suppl., 181s-187s.

Barrett-Connor E \& Khaw KT (1987) Cigarette smoking and increased endogenous estrogen levels in men. American Journal of Epidemiology 126, 187-192.

Bélanger A, Locong A, Noel C, Cusan L, Dupont A, Prévost J, Caron S \& Sévigny J (1989) Influence of diet on plasma steroid and sex plasma binding globulin levels in adult men. Journal of Steroid Biochemistry 32, 829-833.

Belis JA (1980) Methodological basis for the radioimmunoassay of endogenous steroids in human prostatic tissue. Investigative Urology 17, 332-336.

Birkett AM, Jones GP, de Silva AM, Young GP \& Muir JG (1997). Dietary intake and faecal excretion of carbohydrate by Australians: importance of achieving stool weights greater than $150 \mathrm{~g}$ to improve faecal markers relevant to colon cancer risk. European Journal of Clinical Nutrition 51, 625-632.

Bishop TD, Meikle AW, Slattery ML, Stringham JD, Ford MH \& West DW (1988) The effect of nutritional factors on sex hormone levels in male twins. Genetic Epidemiology 5, 43-59.

Bowey EA, Rowland IR, Adlercreutz H, Sanders TAB \& Wiseman H (1988) Inter-individual variation in soya-bean isoflavone metabolism: the role of habitual diet. Proceedings of the Nutrition Society 57, 161A.

Brotherhood JR (1984) Nutrition and preventative medicine. Sports Medicine 1, 350-389.

Bruchovsky N, Rennie PS, Batzold FH, Goldenberg SL, Fletcher T \& McLoughlin MG (1988) Kinetic parameters of $5 \alpha$-reductase activity in stroma and epithelium of normal, hyperplastic, and carcinomatous human prostates. Journal of Clinical Endocrinology and Metabolism 67, 806-816.

Bruning PF \& Bonfrer JMG (1986) Free fatty acid concentrations correlated with the available fraction of estradiol in human plasma. Cancer Research 46, 2606-2609. 
Brzezinski A, Adlercreutz H, Shaoul R, Rösler A, Shmueli A, Tanos V \& Schenker JG (1997) Short-term effects of phytoestrogen-rich diet on postmenopausal women. Menopause 4, 89-94.

Cassidy A, Faughnan M, Hughes R, Fraser C, Cathcart A, Taylor N, Setchell KDR \& Bingham S (1998) Hormonal effects of phytoestrogens in postmenopausal women and middle-aged men. American Journal of Clinical Nutrition 68, 1531A.

Coffey DS \& Isaacs JT (1981) Control of prostate growth. Urology 13, Suppl., 17s-24s.

Cooke RR, McIntosh JEA \& McIntosh RP (1993) Circadian variation in serum free and non-SHBG-bound testosterone in normal men: measurements, and simulation using a mass action model. Clinical Endocrinology 39, $163-171$.

Cummings JH, Wiggins HS, Jenkins DJ, Houston H, Jivraj T, Drasar BS \& Hill MJ (1978) Influence of diets high and low in animal fat on bowel habit, gastrointestinal transit time, fecal microflora, bile acids and fat excretion. Journal of Clinical Investigation 61, 953-963.

Dai WS, Gutai JP, Kuller LH \& Cauley JA (1988) Cigarette smoking and serum sex hormones in men. American Journal of Epidemiology 128, 796-805.

Dai WS, Kuller LH, LaPorte RE, Gutai JP, Falvo-Gerard L \& Caggiula A (1981) The epidemiology of plasma testosterone levels in middle-aged men. American Journal of Epidemiology 114, 804-816.

De Jong FH, Oishi K, Hayes RB, Bogdanowicz JF, Raatgever JW, van der Mass PS, Yoshida O \& Schroeder FH (1991) Peripheral hormone levels in controls and patients with prostate cancer or benign prostatic hyperplasia: results from the Dutch-Japanese case-control study. Cancer Research 51, 3445-3450.

Denis L, Morton MS \& Griffiths K (1999) Diet and its preventative role in prostatic disease. European Urology 35, $377-387$.

Deslypere JP \& Vermeulen A (1984) Leydig cell function in normal men: effect of age, life-style, residence, diet and activity. Journal of Clinical Endocrinology and Metabolism 59, 955-962.

Distiller LA, Sagel J, Dubowitz B, Kay G, Carr PJ, Katz M \& Kew MC (1976) Pituitary-gonadal function in men with alcoholic cirrhosis of the liver. Hormone and Metabolic Research 8, 461-465.

Diver MJ (1993) The effects of free fatty acids on the in vitro binding of testosterone in human plasma. Journal of Endocrinology 136, 327-330.

Dorgan JF, Judd JT, Longcope C, Brown C, Schatzkin A, Clevidence BA, Campbell WS, Nair PN, Franz C, Kahle L \& Taylor PR (1996) Effects of dietary fat and fiber on plasma and urine androgens and estrogens in men: a controlled feeding study. American Journal of Clinical Nutrition 64, 850-855.

Duncan S, Blacklaw J, Beastall GH \& Brodie MJ (1999) Antiepileptic drug therapy and sexual function in men with epilepsy. Epilepsia 49, 197-204.

Dunn JF, Nisula BC \& Rodbard D (1981) Transport of steroid hormones: binding of 21 endogenous steroid to both testosterone-binding globulin and corticosteroid-binding globulin in human plasma. Journal of Clinical Endocrinology and Metabolism 53, 58-68.

Ehrlichman RJ, Issacs JT \& Coffey DS (1981) Differences of the effects of estradiol on DHT-induced prostatic growth of the castrate dog and rat. Investigative Urology 18, 466-470.

Ellingboe J (1987) Acute effects of ethanol on sex hormones in non-alcoholic men and women. Alcohol and Alcoholism 1, Suppl., 109s-116s.

Ellis L \& Nyborg H (1992) Racial/ethnic variations in male testosterone levels: a probable contributor to group differences in health. Steroids 57, 72-75.

Evans BAJ, Griffiths K \& Morton MS (1995) Inhibition of $5 \alpha$-reductase in genital skin fibroblasts and prostate tissue by dietary lignans and isoflavonoids. Journal of Endocrinology 147, 295-302.

Farnsworth WE (1996) Roles of estrogen and sex hormone-binding globulin in prostate physiology. Prostate 28, 17 23.

Ferrini RL \& Barrett-Connor E (1998) Sex hormones and age: a cross-sectional study of testosterone and estradiol and their bio-available fractions in community-dwelling men. American Journal of Epidemiology 147, $750-754$.

Field AE, Colditz GA, Willett WC, Longcope C \& McKinlay JB (1994) The relation of smoking, age, relative weight and dietary intake to serum adrenal steroids, sex hormones and sex hormone-binding globulin in middle-aged men. Journal of Clinical Endocrinology and Metabolism 79, 1310-1316.

Foppiani L, Uva V, Falivene M, Valenti S, Traversa C, Rasore E \& Giusti M (1997) Anorexia nervosa: a follow-up of nutritional, hormonal and psychiatric parameters. Minerva Medica 86, 537-542.

Gann PH, Hennekens CH, Ma J, Longcope C \& Stampfer MJ (1996) Prospective study of sex hormone levels and risk of prostate cancer. Journal of the National Cancer Institute 88, 1118-1126.

Giles G \& Ireland P (1997) Diet, nutrition and prostate cancer. International Journal of Cancer 10, Suppl., 13s-17s.

Glass AR, Swerdloff RS, Bray GA, Dahms WT \& Atkinson RL (1977) Low serum testosterone and sex hormonebinding globulin in massively obese men. Journal of Clinical Endocrinology 45, 1211-1219.

Goldin BR, Adlercreutz H, Gorbach SL, Warram JH, Dwyer JT, Swenson L \& Woods MN (1982) Estrogen excretion patterns and plasma levels in vegetarian and omnivorous women. New England Journal of Medicine 307, 15421547.

Goldin BR \& Gorbach SL (1976) The relationship between diet and rat fecal bacterial enzymes implicated in colon cancer. Journal of the National Cancer Institute 57, 371-375.

Goldin BR, Swenson L, Dwyer J, Sexton M \& Gorbach SL (1980) Effect of diet and Lactobacillus acidophilus supplements on human fecal bacterial enzymes. Journal of the National Cancer Institute 64, 255-261. 
Goldin BR, Woods MN, Spiegelman DL, Longcope C, Morrill-LaBrode A, Dwyer JT, Gualtieri LJ, Hertzmark E \& Gorbach SL (1994) The effect of dietary fat and fiber on serum estrogen concentrations in pre-menopausal women under controlled dietary conditions. Cancer 74, Suppl., 1125s-1131s.

Goldman J, Wajchenberg B, Liberman M, Nery S, Achando S \& Germek OA (1985) Contrast analysis for the evaluation of the circadian rhythms of plasma cortisol, androstenedione and testosterone in normal men and the possible influence of meals. Journal of Clinical Endocrinology and Metabolism 60, 164-167.

Gooren LJG (1996) The age-related decline of androgen levels in men: clinically significant? British Journal of Andrology 78, 763-768.

Gordon GG, Altman K, Southren AL, Rubin E \& Lieber CS (1976) Effect of alcohol (ethanol) administration on sexhormone metabolism in normal men. New England Journal of Medicine 295, 793-797.

Gray A, Berlin JA, McKinlay JB \& Longcope C (1991) An examination of research design effects on the association of testosterone and male aging: results of a meta-analysis. Journal of Clinical Epidemiology 44, 671-684.

Groh H, Schade K \& Horhold-Schubert C (1993) Steroid metabolism with intestinal micro-organisms. Journal of Basic Microbiology 33, 59-72.

Haffner SM (1996) Sex hormone-binding globulin protein, hyperinsulinaemia, insulin resistance and non-insulindependent diabetes. Hormone Research 45, 233-237.

Haffner SM, Valdez RA, Mykkanen L, Stern MP \& Katz MS (1994) Decreased testosterone and dehydroepiandrosterone sulphate concentrations are associated with increased insulin and glucose concentrations in non-diabetic men. Metabolism 43, 599-603.

Hämäläinen E, Adlercreutz H, Puska P \& Pietinen P (1984) Diet and serum sex hormones in healthy men. Journal of Steroid Biochemistry 20, 459-464.

Henderson BE, Bernstein L, Ross RK, Depue RH \& Judd HL (1988) The early in utero oestrogen and testosterone environment of blacks and whites: potential effects on male offspring. British Journal of Cancer 57, 216-218.

Hill P, Wynder E, Garbaczewski L, Garnes H, Walker ARP \& Helman P (1980) Plasma hormones and lipids in men at different risk for coronary heart disease. American Journal of Clinical Nutrition 33, 1010-1018.

Hill P, Wynder EL, Garbaczewski L \& Walker ARP (1982) Effect of diet on plasma and urinary hormones in South African black men with prostatic cancer. Cancer Research 42, 3864-3869.

Howie BJ \& Shultz TD (1985) Dietary and hormonal interrelationships among vegetarian Seventh Day Adventists and non-vegetarian men. American Journal of Clinical Nutrition 42, 127-134.

Hsieh CC, Signorello LB, Lipworth L, Lagiou P, Mantzoros CS \& Trichopoulos D (1998) Predictors of sex hormone levels among the elderly: a study in Greece. Journal of Clinical Epidemiology 51, 837-841.

Hughes R, Cassidy A \& Bingham S (1994) Hormonal effects of lignans in a group of men. Proceedings of the Nutrition Society 53, 230A.

Hutchins AM, Slavin JL \& Lampe JW (1995) Urinary isoflavonoid phytoestrogen and lignan excretion after consumption of fermented and unfermented soy products. Journal of the American Dietetic Association 95, 545551.

Järvenpää P, Kosunen T, Fotsis T \& Adlercreutz H (1980) In vitro metabolism of estrogens by isolated intestinal microorganisms and by human faecal microflora. Journal of Steroid Biochemistry 13, 345-349.

Jenkins DJA, Wolever TMS, Leeds AR, Gassull MA, Haisman P, Dilawari J, Goff DR, Metz GL \& Alberti KG (1978) Dietary fibres, fibre analogues and glucose tolerance: importance of viscosity. British Medical Journal 1, 13921394.

Jin F, Devesa SS, Zheng W, Blot WJ, Fraumeni JF Jr \& Gao YT (1999) Cancer incidence trends in urban Shanghai, 1972-1989. International Journal of Cancer 53, 764-770.

Kaiser FE, Viosca SP, Morley JE, Mooradian AD, Davis SS \& Korenman SG (1988) Impotence and aging: clinical and hormonal factors. Journal of the American Geriatrics Society 36, 511-519.

Kaufman JM, Deslypere JP, Giri M \& Vermeulen A (1990) Neuroendocrine regulation of pulsatile luteinizing hormone secretion in elderly men. Journal of Steroid Biochemistry and Molecular Biology 37, 421-430.

Kay RM \& Strasberg SM (1978) Origin, chemistry, physiological effects and clinical importance of dietary fibre. Clinical and Investigative Medicine 1, 9-24.

Key TJA, Pike MC, Moore JW, Wang DY \& Morgan B (1990b) The relationship of free fatty acids with the binding of oestradiol to sex hormone-binding globulin and to albumin in women. Journal of Steroid Biochemistry 35, $35-38$.

Key TJA, Roe L, Thorogood M, Moore JW, Clark GM \& Wang DY (1990a) Testosterone, sex hormone-binding globulin, calculated free testosterone and oestradiol in male vegans and omnivores. British Journal of Nutrition 64, $111-119$.

Kletter GB, Padmanabhan V, Beitins IZ, Marshall JC, Kelch RP \& Foster CM (1997) Acute effects of estradiol infusion and naloxone on luteinising hormone secretion in pubertal boys. Journal of Clinical Endocrinology and Metabolism 82, 4010-4014.

Kley HK, Deselaers T, Peerenboom H \& Kruskemper HL (1980b) Enhanced conversion of androstenedione to estrogens in obese males. Journal of Clinical Endocrinology and Metabolism 51, 1128-1132.

Kley HK, Edelmann P \& Kruskemper HL (1980a) Relationship of plasma sex hormones to different parameters of obesity in male subjects. Metabolism 29, 1041-1045. 
Korenman SG, Morley JE, Mooradian AD, Davis SS, Kaiser FE, Silver AJ, Viosca SP \& Garza D (1990) Secondary hypogonadism in older men: its relationship to impotence. Journal of Clinical Endocrinology and Metabolism 71, 963-969.

Krenz LE, Rose RM \& Jennings JR (1972) Suppression of plasma testosterone levels and psychological stress: a longitudinal study of young men in office candidate school. Archives of General Psychiatry 26, 479-482.

Kubricht WS, III, Williams BJ, Whatley T, Pinckard P \& Eastham JA (1999) Serum testosterone levels in AfricanAmerican and white men undergoing prostate biopsy. Urology 54, 1035-1038.

Lado-Abeal JH, Prieto D, Lorenzo M, Lojo S, Febrero M, Camarero E \& Cabezas-Cerrato J (1999) Differences in men and women as regards the effects of protein-energy malnutrition on the hypothalamic-pituitary-gonadal axis. Nutrition 15, 351-358.

Lampe JW, Martini MC, Kurzer MS, Adlercreutz H \& Slavin JL (1994) Urinary lignan and isoflavonoid excretion in premenopausal women consuming flaxseed powder. American Journal of Clinical Nutrition 60, $122-128$.

Lazarus R, Sparrow D \& Weiss S (1998) Temporal relations between obesity and insulin: longitudinal data from the Normative Aging Study. American Journal of Epidemiology 147, 173-179.

Lecomte P, Lecureuil N, Lecureuil M, Lemonnier Y, Mariotte N, Valat C \& Garrigue MA (1998) Sex differences in the control of sex hormone-binding globulin in the elderly: role of insulin-like growth factor-I and insulin. European Journal of Endocrinology 139, 178-183.

Lee PA, Bellinger MF \& Coughlin MT (1998) Correlations among hormone levels, sperm parameters and paternity in formerly unilaterally cryptorchid men. Journal of Urology 160, 1155-1157.

Lewis SL, Heaton KW, Oakey RE, McGarrigle HH (1997) Lower serum oestrogen concentrations associated with faster intestinal transit. British Journal of Cancer 76, 395-400.

Liu PY, Turner L, Rushford D, McDonald J, Baker HW, Conway AJ \& Handelsman DJ (1999) Efficacy and safety of recombinant human follicle stimulating hormone (Gonal-F) with urinary human chorionic gonadotrophin for induction of spermatogenesis and fertility in gonadotrophin-deficient men. Human Reproduction 14, 15401545.

Longcope C, Feldman HA, McKinlay JB \& Araujo AB (2000) Diet and sex hormone-binding globulin. Journal of Clinical Endocrinology and Metabolism 85, 293-296.

Lookingbill DP, Demers LM, Wang C, Leung A, Rittmaster RS \& Santen RJ (1991) Clinical and biological parameters of androgen action in normal healthy Caucasian versus Chinese subjects. Journal of Clinical Endocrinology and Metabolism 72, 1241-1248.

Loukovaara M, Carson M, Palotie A \& Adlercreutz H (1995) Regulation of sex hormone-binding globulin production by isoflavonoids and patterns of isoflavonoid conjugation in HepG2 cell cultures. Steroids 60, 656-661.

Lu LJW, Anderson KE, Grady JJ \& Nagamini M (1996) Effects of soya consumption for one month on steroid hormones in premenopausal women: implications for breast cancer reduction. Cancer Epidemiology, Biomarkers and Prevention 5, 63-70.

Lu LJW, Anderson KE, Nealon W \& Nagamini M (1998) One month of soy consumption reduces concentrations of circulating steroid hormones and cholecystokinin in men and women. American Journal of Clinical and Nutrition 68, $1531 \mathrm{~A}$.

Lu LJW, Grady JJ, Marshall MV, Sadagopa Ramanujam VM \& Anderson KE (1995) Altered time course of urinary daidzein and genistein excretion during chronic soya diet in healthy male subjects. Nutrition and Cancer 24, 311323.

Manni A, Pardridge WM, Cefalu W, Nisula BC, Bardin CW, Santner SJ \& Santen RS (1985) Bioavailability of albumin-bound testosterone. Journal of Clinical Endocrinology and Metabolism 61, 705-710.

Markiewicz L, Garey J, Adlercreutz H \& Gurpide E (1993) In vitro bioassays of non-steroidal phytoestrogens. Journal of Steroid Biochemistry and Molecular Biology 45, 399-405.

Martin ME, Vranckx R, Benassayag C \& Nunez EA (1986) Modifications of the properties of human sex steroidbinding protein by nonesterified fatty acids. Journal of Biological Chemistry 261, 2954-2959.

Marynick SP, Loriaux DL, Sherins RJ, Pita JC Jr \& Lipsett MB (1979) Evidence that testosterone can suppress pituitary gonadotrophin secretion independently of peripheral aromatization. Journal of Clinical Endocrinology and Metabolism 49, 396-398.

Matzkin H \& Soloway MS (1993) Cigarette smoking: a review of possible associations with benign prostatic hyperplasia and prostate cancer. Prostate 22, 277-290.

Miller SL \& Wolfe RR (1999) Physical exercise as a modulator of adaptation to low and high carbohydrate and low and high fat intakes. European Journal of Clinical Nutrition 52, Suppl. 1, 112s-119s.

Morley JE, Kasier FE, Perry HM III, Patrick P, Morley PMK, Stauber PM, Vellas B, Baumgartner RN \& Garry PJ (1997) Longitudinal changes in testosterone, luteinising hormone and follicle-stimulating hormone in healthy older men. Metabolism 46, 410-413.

Mousavi Y \& Adlercreutz H (1993) Genistein is an effective stimulator of sex hormone-binding globulin production in hepatocarcinoma in human liver cancer cells and suppresses proliferation of these cells in culture. Steroids 58, $301-$ 304.

Nagata C, Kabuta M, Kurisu Y \& Shimizu H (1997) Decreased serum estradiol concentration associated with high dietary intake of soy products in premenopausal Japanese women. Nutrition and Cancer 29, 228-233.

Nahoul K \& Roger M (1990) Age-related decline of plasma bio-available testosterone in adult men. Journal of Steroid Biochemistry 35, 293-299. 
Nilsson PM, Moller L \& Solstad K (1995) Adverse effects of psychological stress on gonadal function and insulin levels in middle-aged men. Journal of Internal Medicine 237, 479-486.

Parkin OM, Muir CS, Whelan S, Gao T, Ferlay J \& Powell J (1992) Cancer Incidence in Five Continents, vol. 6 International Agency for Research into Cancer Scientific Publication no. 120. Lyon, France: International Agency for Research into Cancer.

Pasquali R, Casimirri F, De Iasio R, Mesini P, Boschi S, Chierici B, Flamia R, Biscotti M \& Vicennati V (1995) Insulin regulates testosterone and sex hormone-binding globulin concentrations in adult normal-weight and obese men. Journal of Clinical Endocrinology and Metabolism 80, 654-658.

Pasquali R, Macor C, Vicennati V, Novo F, De lasio R, Messini P, Boschi S, Casimirri F \& Vettor R (1997) Effects of acute hyperinsulinemia on testosterone serum concentrations in adult obese and normal-weight men. Metabolism 46, $526-529$.

Pelissero C, Lenczowski MJP, Chinzi D, Davailcuisset B, Stumpter JP \& Fostier A (1996) Effects of flavonoids on aromatase activity: an in vitro study. Journal of Steroids, Biochemistry and Molecular Biology 57, $215-223$.

Phipps WR, Martini MC, Lampe JW, Slavin JL \& Kurzer MS (1993) Effect of flaxseed ingestion on the menstrual cycle. Journal of Clinical Endocrinology and Metabolism 77, 1215-1219.

Plymate SR, Jones RE, Matej LA \& Freidl KE (1988) Regulation of sex hormone-binding globulin (SHBG) production in Hep G2 cells by insulin. Steroids 52, 339-340.

Pusateri DJ, Roth WT, Ross JK \& Shultz TD (1990) Dietary and hormonal evaluation of men at different risks for prostate cancer: plasma and fecal hormone-nutrient interrelationships. American Journal of Clinical Nutrition 51, $371-377$.

Raben A, Kiens B, Richter EA, Rasmussen LB, Svenstrup B, Micic S \& Bennett P (1992) Serum sex hormones and endurance performance after a lacto-ovo-vegetarian and a mixed diet. Medicine and Science in Sports and Exercise 24, 1290-1297.

Reddy BS, Hanson D, Mangat S, Matthews L, Sbaschnig M, Sharma C \& Simi B (1980) Effect of high-fat, high-beef diet and of mode of cooking of beef in the diet on fecal bacterial enzymes and fecal bile acids and neutral sterols. Journal of Nutrition 110, 1880-1887.

Reed MJ, Cheng RW, Beranek PA, Few JD, Franks S, Ghilchik MW \& James VH (1986) The regulation of the biologically available fractions of oestradiol and testosterone in plasma. Journal of Steroid Biochemistry 24, $317-320$.

Reed MJ, Cheng RW, Simmonds M, Richmond W \& James VHT (1987) Dietary lipids: an additional regulator of plasma levels of sex hormone-binding globulin. Journal of Clinical Endocrinology and Metabolism 64, $1083-1085$.

Rittmaster RS, Zwicker H, Thompson DL, Konok G \& Norman RW (1993) Androstanediol glucuronide production in human liver, prostate and skin: evidence for the importance of the liver in $5 \alpha$-reduced androgen metabolism. Journal of Clinical Endocrinology and Metabolism 76, 977-982.

Rose DP, Boyar AP \& Wynder EL (1986) International comparisons of mortality rates for cancer of the breast, ovary, prostate and colon, and per capita food consumption. Cancer 58, 2362-2371.

Rose DP, Goldman M, Connolly JM \& Strong LE (1991) High-fiber diet reduces serum estrogen concentrations in premenopausal women. American Journal of Clinical Nutrition 54, 520-525.

Rosenthal MB, Barnard RJ, Rose DP, Inkeles S, Hall J \& Pritikin N (1985) Effects of high-complex carbohydrate, lowfat, low-cholesterol diet on levels of serum lipids and estradiol. American Journal of Medicine 78, 23-27.

Rosner W (1990) The functions of corticosteroid-binding globulin and sex hormone-binding globulin: recent advances. Endocrine Reviews 11, 80-91.

Ross JK, Pusateri DJ \& Shultz TD (1990) Dietary and hormonal evaluation of men at different risks of prostate cancer: fiber intake, excretion and composition, with in vitro evidence for an association between steroid hormones and specific fiber components. American Journal of Clinical Nutrition 51, 365-370.

Ross R, Bernstein L, Judd H, Hanisch R, Pike M \& Henderson B (1986) Serum testosterone levels in healthy young black and white men. Journal of the National Cancer Institute 76, 45-48.

Ross RK, Bernstein L, Lobo RA, Shimizu H, Stanczyk FZ, Pike MC \& Henderson BE (1992) $5 \alpha$-reductase activity and risk of prostate cancer among Japanese and U.S. white and black males. Lancet 339, 887-889.

Santer SJ, Albertson B, Zhang G-Y, Zhang G-H, Santulli M, Wang C, Demers LM, Shackleton C \& Santen RJ (1998) Comparative rates of androgen production and metabolism in Caucasian and Chinese subjects. Journal of Clinical Endocrinology and Metabolism 83, 2104-2109.

Sapin R, Schlienger JL, Gasser F \& Chambron J (1992) Changes in serum testosterone levels after myocardial infarction. Journal of Nuclear Biology and Medicine 36, 20-25.

Sathyamoorthy N, Wang TTY \& Phang JM (1994) Stimulation of pS2 expression by diet-derived compounds. Cancer Research 54, 957-961.

Schneider G, Kirschner MA, Berkowitz R \& Ertel NH (1979) Increased estrogen production in obese men. Journal of Clinical Endocrinology and Metabolism 48, 633-638.

Setchell KDR (1998) Phytoestrogens: the biochemistry, physiology and implications for human health of soy isoflavones. American Journal of Clinical Nutrition 68, Suppl., 133S-146S.

Shetty PS \& Kurpad AV (1986) Increasing starch intake in the human diet increases fecal bulking. American Journal of Clinical Nutrition 43, 210-212.

Shultz TD \& Howie DJ (1986) In vitro binding of steroid hormones by natural and purified fibres. Nutrition and Cancer 8, $141-147$. 
Shultz TD, Bonorden WR \& Seaman WR (1991) Effect of short-term flaxseed consumption on lignan and sex hormone metabolism in men. Nutrition Research 11, 1089-1100.

Simon D, Preziosi P, Barrett-Connor E, Roger M, Saint-Paul M, Nahoul K \& Papoz L (1992) The influence of aging on plasma sex hormones in men: the Telecom study. American Journal of Epidemiology 135, 783-791.

Smith U (1994) Carbohydrates, fat and insulin action. American Journal of Clinical Nutrition 59, Suppl., 686s689 s.

Stark AH, Switzer BR, Atwood JR, Travis RG, Smith JL, Ullrich F, Ritenbaugh C, Hatch J \& Wu X (1998) Estrogen profiles in postmenopausal African-American women in a wheat bran fiber intervention study. Nutrition and Cancer 31, 138-142.

Stefanick ML, Williams PT, Krauss RM, Terry RB, Vranizan KM \& Wood PD (1987) Relationships of plasma estradiol, testosterone, sex hormone-binding protein with lipoproteins, apolipoproteins, and high density lipoprotein sub-fractions in men. Journal of Clinical Endocrinology and Metabolism 64, 723-729.

Strain G, Zumoff B, Rosner W \& Pi-Suyner X (1994) The relationship between serum levels of insulin and sex hormone-binding globulin in men: the effect of weight loss. Journal of Clinical Endocrinology and Metabolism 79 , $1173-1176$.

Suzuki H, Tominaga T, Kumagai H \& Saruta T (1988) Effects of first-line antihypertensive agents on sexual function and sex hormones. Journal of Hypertension 6, Suppl., 649s-651s.

Tchernof A, Labrie F, Bélanger A, Prud'homme D, Bouchard C, Tremblay A, Nadeau A \& Despres JP (1997) Relationships between endogenous steroid hormones, SHBG and lipoprotein levels in men: contribution of visceral obesity, insulin levels and other metabolic variables. Atherosclerosis 133, 235-244.

Theorell TK, Karasek RA \& Eneroth P (1990) Job strain variations in relation to plasma testosterone fluctuations in working men - a longitudinal study. Journal of Internal Medicine 227, 31-36.

Thigpen AE, Silver TI, Guileyardo JM, Casey ML, McConnell JD \& Russell DW (1993) Tissue distribution and ontogeny of steroid $5 \alpha$-reductase isozyme expression. Journal of Clinical Investigation 92, 903-910.

Thompson LU, Robb P, Serraino M \& Cheung F (1991) Mammalian lignan production from various foods. Nutrition and Cancer 16, 43-52.

Thorsdottir I, Anderson H \& Einarsson S (1998) Sugar beet fiber in formula diet reduces postprandial blood glucose, serum insulin and serum hydroxyproline. European Journal of Clinical Nutrition 51, 155-156.

Tomova A \& Kumanov P (1999) Sex differences and similarities of hormonal alternation in patients with anorexia nervosa. Andrologia 31, 143-147.

Valero-Politi J \& Fuentes-Arderiu X (1993) Within- and between-subject biological variations of follitropin, lutropin, testosterone and sex hormone-binding globulin in men. Clinical Chemistry 39, 1723-1725.

Valimaki M, Salaspuro M, Härkönen M \& Ylikahri R (1982) Liver damage and sex hormones in chronic male alcoholics. Clinical Endocrinology 17, 469-477.

Vegetarian Society UK (2000) Summary of RealEat polls, 1984-1999. Vegetarian Society Information Sheet. http:॥www.vegsoc.org/info/realeat.html accessed 25.4.2000.

Vermeulen A, Kaufman JM, Deslypere JP \& Thomas G (1993) Attenuated luteinising hormone (LH) pulse amplitude but normal LH pulse frequency, and its relation to plasma androgens in hypogonadism of obese men. Journal of Clinical Endocrinology and Metabolism 76, 1140-1146.

Vermeulen A, Kaufman JM \& Giagulli VA (1996) Influence of some biological indexes on sex hormone-binding globulin and androgen levels in aging or obese males. Journal of Clinical Endocrinology and Metabolism 81, 1821 1826.

Vermeulen A \& Verdonck G (1992) Representativeness of a single point plasma testosterone level for the long term hormonal milieu in men. Journal of Clinical Endocrinology and Metabolism 74, 939-942.

Warren MP, Voussoughian F, Geer EB, Hyle EP, Adberg CL \& Ramos RH (1999) Functional hypothalamic amenorrhea: hypoleptinemia and disordered eating. Journal of Clinical Endocrinology and Metabolism 84, 873877.

Wilding G (1995) Endocrine control of prostate cancer. In Preventing Prostate Cancer: Screening vs. Chemoprevention. Cancer Surveys, vol. 23 [RTD Olliver, A Belldegrum and PFM Wrigley, editors]. Cold Spring Harbor, NY: Cold Spring Harbor Lab Press.

Winters SJ \& Atkinson L (1997) Serum luteinising hormone concentrations in hypogonadal men during transdermal testosterone replacement through scrotal skin: further evidence that ageing enhances testosterone negative feedback. The Testoderm Study Group. Clinical Endocrinology 47, 317-322.

World Health Organization (1985) Energy and Protein Requirements. Report of a Joint FAO/WHO/UNU Expert Consultation. WHO Technical Report Series no. 724. Geneva: WHO.

Wu AH, Whittemore AS, Kolonel LN, John EM, Gallagher RP, West DW, Hankin J, The CZ, Dreon DM \& Paffenbarger RS Jr (1995) Serum androgens and sex hormone-binding globulin in relation to lifestyle factors in older African-American, white and Asian men in the United States and Canada. Cancer Epidemiology, Biomarkers and Prevention 4, 735-741.

Ylikahri RH, Huttunen MO, Härkönen M, Leino T, Helenius T, Liewendahl K \& Karonen SL (1978) Acute effects of alcohol on anterior pituitary secretion of the trophic hormones. Journal of Clinical Endocrinology and Metabolism 46, 715-720.

Yu H, Harris RE, Gao YT \& Wynder LE (1991) Comparative epidemiology of cancers of the colon, rectum, prostate and breast in Shanghai, China versus the US. International Journal of Epidemiology 20, 76-81. 
Zumoff B, Strain GW, Kream J, O’Connor J, Levin J \& Fukushima DK (1981) Obese young men have elevated plasma oestrogen levels but obese premenopausal women do not. Metabolism 30, 1011-1014.

Zwart AD, Urban RJ, Odell WD \& Veldhuis JD (1996) Contrasts in the gonadotrophin-releasing hormone doseresponse relationships for luteinising hormone, follicle-stimulating hormone and alpha-subunit release in young versus older men: appraisal with high specificity immunoradiometric assay and deconvolution analysis. European Journal of Endocrinology 135, 399-406. 